\title{
PENGARUH KOMPENSASI DAN DISIPLIN KERJA TERHADAP KINERJA PEGAWAI KANTOR BPJS KESEHATAN CABANG PALU
}

\author{
ANDI ARMANSYAH \\ IDRIS AZIS \\ NILUH PUTU EVVY ROSSANTY \\ Program Studi S1 Manajemen Fakultas Ekonomi Universitas Tadulako \\ Email: andhy.armansyah@yahoo.com
}

\begin{abstract}
This study aims to determine the effect of compensation and Discipline Work either simultaneously or partially on the Performance of BPJS Health Office Employee Branch Palu. The independent variables used in this study are compensation and Work Discipline. While the dependent variable is Performance. The method used in this research is quantitative descriptive method. The type of research conducted is replication research. The sample was 36 respondents with sampling technique of saturated sample method. Data analysis method used in this study is multiple linear regression analysis method using spss 21 . The results of this study indicate that simultaneously compensation and Work Discipline have a significant effect on Employee Performance Office BPJS Health Branch Palu. And partially compensation and work discipline have a significant effect on the performance of employees BPJS Branch Office Health Palu.
\end{abstract}

Keywords: compensation, work disciplin, performance

\begin{abstract}
ABSTRAK
Penelitian ini bertujuan untuk mengetahui pengaruh kompensasi dan disiplin kerjabaik secara simultan maupun parsialterhadap Kinerja Pegawai Kantor BPJS Kesehatan Cabang Palu. Variabel independen yang digunakan dalam penelitian ini adalah kompensasi dan disiplin kerja. Sedangkan variabel dependen adalah kinerja. Metode yang digunakan dalam penelitian ini adalah metode deskriptifkuantitatif. Jenis penelitian yang dilakukan adalah penelitian replikasi. Sampel berjumlah 36 responden dengan teknik pengambilan sampel adalah metode sampel jenuh. Metode analisis data yang digunakan dalam penelitian ini adalah metode analisis regresi linear berganda dengan menggunakan spss 21. Hasil penelitian ini menunjukkan bahwa secara simultan kompensasi dan disiplin kerja berpengaruh signifikan terhadap Kinerja Pegawai Kantor BPJS Kesehatan Cabang Palu.Dan secara parsial kompensasi dan disiplin kerja berpengaruh signifikan terhadap kinerja pegawai Kantor BPJS Kesehatan Cabang Palu.
\end{abstract}

Kata Kunci: kompensasi, disiplin kerja, kinerja

\section{PENDAHULUAN}

Sumber daya manusia mempunyai fungsi yang penting dalam pencapaian produktivitas kerja oleh karena itu tenaga kerja perlu dipacu kinerjanya, mengingat bahwa sumber daya manusialah yang mengatur atau mengelola sumber-sumber daya lainnya, dengan demikian berhasil tidaknya suatu proses pekerjaan lebih banyak tergantung pada unsur manusianya. Betapa hebat dan canggihnya peralatan dan teknologi serta didukung modal yang besar, tetapi bila manusianya tidak mampu untuk menangani secara efektif dan efisien, tujuan perusahaan tidak akan tercapai, yaitu mendapatkan laba agar perusahaan bisa tumbuh dan berkembang. Secara otomatis berarti tingkat kinerja karyawanpun rendah. Jadi untuk mendorong kinerja seorang karyawan, pimpinan perusahaan harus memberikan kompensasi untuk mencapai kinerja karyawan yang memuaskan, Karena kompensasi merupakan hubungan dari timbal balik antara perusahaan dan sumber daya manusia.

Menurut Umar (2007:16) kompensasi adalah segala sesuatu yang diterima oleh pegawai berupa gaji, upah, insentif, bonus, premi, pengobatan, asuransi dan lain-lain yang sejenis yang di bayar langsung perusahaan.Menurut Rivai (2003) disiplin kerja adalah suatu alat yang digunakan para manajer untuk berkomunikasi dengan karyawan agar mereka bersedia untuk mengubah sesuatu 
Armansyah, A.

perilaku serta sebagai suatu upaya untuk meningkatkan kesadaran dan kesediaan seseorang menaati semua peraturan perusahaan dan norma-norma sosial yang berlaku.

Menurut Mangkunegara (2012) kinerja merupakan hasil kerja secara kualitas dan kuantitas yang dicapai oleh seorang pegawai dalam melaksanakan tugasnya sesuai dengan tanggung jawab yang diberikan kepadanya.BPJS (badan penyelenggara jaminan sosial) kesehatan merupakan badan hukum publik yang bertanggung jawab langsung kepada presiden dan memiliki tugas untuk menyelenggarakan jaminan kesehatan nasional bagi seluruh rakyat Indonesia, terutama untuk pegawai negri sipil, penerima pensiun PNS dan TNI/POLRI, veteran, perintis kemerdekaan beserta keluarganya dan badan usaha lainnya ataupun rakyat biasa. BPJS Kesehatan merupakan program pemerintah dalam kesatuan jaminan kesehatan beroperasi sejak tanggal 1 januari 2014. BPJS kesehatan sebelumnya bernama Askes (Asuransi kesehatan) yang dikelola oleh PT. Askes Indonesia (persero), namun sesuai dengan UU No. 24 tahun 2011 tentang BPJS, PT. Askes Indonesia berubah menjadi BPJS Kesehatan. Undang-undang Nomor 24 tahun 2011 tentang BPJS, yang merupakan lanjutan dari amanah UndangUndang Nomor 40 tahun 2004 tentang SJSN. Amanah ini mengandung tanggung jawab yang sangat besar karena PT. Askes (persero) menjadi BPJS kesehatan nasional bagi seluruh rakyat Indonesia pada tahun 2019 yang mana pada saat itu, di perkirakan penduduk Indonesia berjumlah sebanyak 268,1 juta jiwa. Tanggung jawab ini, merupakan karunia yang harus dicermati karena menuntut perubahan radikal ditubuh PT. Askes (persero) pada waktu itu, khususnya perubahan budaya yang harus ditopang oleh kesiapan SDM yang handal dan adaptif, serta tanggap terhadap perubahan namun tetap prima dalam memberikan pelayanan. Terdapat dua mandat pokok dalam UU BPJS, yaitu: (1) menyiapkan operasional BPJS kesehatan; (2) menyiapkan pengalihan asset dan liabilitas, pegawai, serta hak dan kewajiban PT Askes (persero) ke BPJS kesehatan.

Fenomena yang menarik di kantor BPJS Kesehatan Cabang Palu yang penulis dapatkan melalui wawancara dari salah satu pegawainya yang berinisial ibu $\mathrm{F}$ yaitu permasalahan mengenai pemberian kompensasi, ibu F merupakan salah satu pegawai yang sudah cukup lama bekerja di kantor BPJS Kesehatan Cabang Palu. Ibu F mengatakan jika dibandingkan ada perbedaan dengan PT. Askes (persero) yang dilihat dari tanggal lamanya bekerja pegawai. dan sekarang menggunakan system target dan prestasi kerja dengan adanya raport yang dibuat setiap triwulan sekali, raport ini dibuat untuk menentukan bonus dan perhitungan tercapainya target kinerja setiap pegawai yang telah ditentukan oleh BPJS kesehatan cabang palu, berdasarkan penjelasan tersebut bonus yang di peroleh akan berbeda-beda sesuai dengan kinerja masing-masing. dengan adanya system baru ini akan menjadi motivasi bagi pegawai untuk bekerja keras.

1. Untuk mengetahui dan menganalisis pengaruh apakah kompensasi dan disiplin kerja secara bersama-sama berpengaruh terhadap kinerja pegawai kantor BPJS Kesehatan Cabang Palu.

2. Untuk mengetahui apakah kompensasi berpengaruh terhadap kinerja pegawai kantor BPJS Kesehatan Cabang Palu

3. Untuk mengetahui apakah disiplin kerja berpengaruh terhadap kinerja pegawai kantor BPJS Kesehatan Cabang Palu.

\section{KAJIAN LITERATUR DAN PENGEMBANGAN HIPOTESIS}

\section{Pengertian Kompensasi}

Kompensasi adalah seluruh imbalan yang diterima karyawan atas hasil kerja karyawan tersebut pada organisasi. Kompensasi bisa berupa fisik maupun non fisik dan harus dihitung diberikan kepada karyawan sesuai dengan pengorbanan yang telah diberikannya kepada organisasi tempat ia bekerja. Kompensasi adalah semua pendapatan yang berbentuk uang, barang langsung atau tidak langsung yang diterima karyawan sebagai imbalan atas jasa yang diberikan kepada organisasi (Hasibuan, 2002). 


\section{Dimensi Kompensasi}

Menurut Rivai (2003) kompensasi lasngsung terdiri dari pembayaran karyawan dalam bentuk upah, gaji, bonus atau komisi. Kompensasi langsung disebut upah dasar yakni upah atau gaji tetap yang seorang pekerja dalam bentuk upah bulanan (salary) atau upah mingguan atau upah tiap jam dalam bekerja (hourly wage)".

1. Gaji dan Upah

Menurut Rachmawati (2008), gaji adalah imbalan balas jasa dalam bentuk uang yang diterima karyawan sebagai konsekuensi dari kedudukannya sebagai seorang karyawan. Upah adalah kata lain dari gaji yang seringkali ditunjukan pada karyawan tertentu, biasanya pada karyawan operasional.

2. Insentif

Jenis kompensasi lain yang diberikan penuh kepada karyawan sebagai imbalan atas kerjanya adalah dalam upah insentif. Perusahaan menetapkan adanya upah insentif untuk menghubungkan keinginan karyawan akan pendaftaran financial tambahan dengan kebutuhan perusahaan akan peningkatan kualitas dan kuantitas kerjanya.

3. Bonus

meningkatkan produktifitas kerja dan semangat kerja karyawan Bonus diberikan apabila karyawan mempunyai profibilitas atau keuntungan dari seluruh penjualan tahun lalu. Penentuan besarnya pemberian bonus adalah berdasarkan kebijakan perusahaan, tidak ada ketetapan yang pasti mengenai bonus yang diberikan.

4. Tunjangan

memberikan beberapa bentuk perlindungan terhadap pengeluaran biaya ekstra yang disebabkan oleh karena kemungkinan terjadinya kecelakaan kerja, sakit atau memberikan rasa aman pegawai dalam menghadapi hari tua.

\section{Pengertian Disiplin Kerja}

Menurut Rivai (2009) disiplin kerja adalah suatu alat yang digunakan para menajer untuk berkomunikasi dengan karyawan agar mereka bersedia untuk mengubah suatu perilaku serta sebagi suatu upaya untuk meningkatkan kesadaran dan kesediaan seorang mentaati semua peraturan perusahaan dan norma-norma sosial yang berlaku. Menurut Hasibuan (2009) kedisiplinan adalah kesadaran dan kesetiaan seseorang menaati semua peraturan perusahaan dan norma-norma sosial yang berlaku. Sutrisno, (2009) disiplin kerja pegawai adalah sikap, tingkah laku, dan perbuatan yang sesuai dengan peraturan dari organisasi baik tertulis maupun yang tidak tertulis.

Berdasarkan uraian di atas dapat disimpulkan bahwa ysng dimaksud dengan disiplin kerja adalah sikap mental yang tercermin dalam perbuatan pereorangan maupun kelompok kepatuhan maupun ketaatan terhadap peraturan-peraturan yang ditetapkan untuk memperteguh pedoman-pedoman organisasi.

\section{Dimensi Disiplin Kerja}

Menurut Soetrisno (1992) ada tiga bentuk disiplin yaitu:

1. Disiplin waktu

Disiplin waktu berarti bersikap factual terhadap waktu yang ditetapkan termasuk jam mulai kerja, jam istrahat, jam pulang kantor dan jam mulai serta penutupan rapat seminar dan lain-lain.

2. Disiplin administrasi

Disiplin administrasi adalah disiplin untuk mengerjakan (atau tidak mengerjakan) seperti yang terteta dalam aturan atau kaedah yang telah

ditetapkan sebelumnya.

3. Disiplin moral

Disiplin moral adalah disiplin yang keluar dari hati nurani untuk berusaha menepati atau menyelesaikan suatu pekerjaan. 


\section{Pengertian Kinerja}

Menurut Mangkunegara (2013), kinerja adalah hasil kerja secara kualitas dan kuantitas yang dicapai oleh seseorang pegawai dalam melaksanakan tugasnya sesua dengan tanggung jawab yang diberikan kepadanya. Menurut Rivai (2008), kinerja merupakan suatu fungsi dari motivasi dan kemampuan untuk menyelesaikan tugas atau pekerjaan seseorang sepatutnya memiliki derajat kesediaan dan tingkat kemampuan tertentu. Irham Fahmi (2010), kinerja adalah hasil yang diperoleh oleh suatu organisasi baik organisasi teersebut bersifat profit oriented dan non profit oriente yang dihasilkan selama satu periode waktu.

\section{Dimensi Kinerja}

Mangkunegara (2015), mengemukakan bahwa ada 4 (empat) dimensi kinerja, yaitu:

1. Kualitas kerja adalah seberapa baik seorang karyawan mengerjakan apa yang seharusnya dikerjakan.

2. Kuantitas kerja adalah seberapa lama seorang pegawai bekerja dalam satu harinya. Kuantitas kerja ini dapat dilihat dari kecepatan kerja setiap pegawai itu masing-masing.

3. Pelaksanaan tugas adalah seberapa jauh karyawan mampu melakukan pekerjaannya dengan akurat atau tidak ada kesalahan.

4. Tanggung jawab terhadap pekerjaan adalah kesadaran akan kewajiban karyawan untuk melaksanakan pekerjaan yang diberikan perusahaan.

\section{Kerangka Pemikiran}

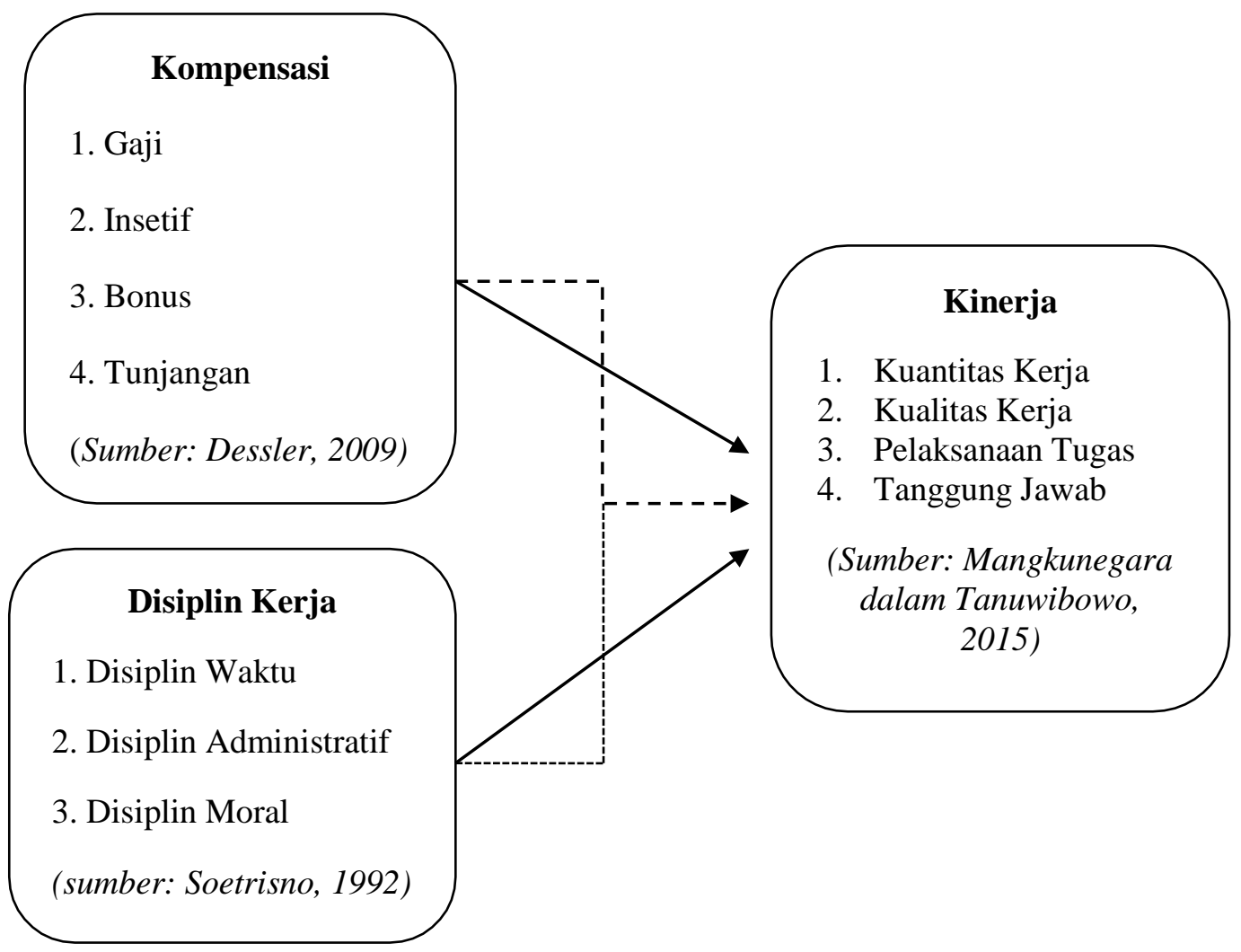

\section{Keterangan:}

Secara simultan:

Secara parsial :

\section{Gambar 1 Kerangka pikir}




\section{Hipotesis}

1. Kompensasi dan Disiplin kerja secara simultam mempunyai pengaruh positif terhadap kinerja pegawai kantor BPJS Kesehatan Cabang Palu.

2. Kompensasi mempunyai pengaruh positif terhadap kinerja pegawai kantor BPJS Kesehatan Cabang Palu.

3. Disiplin kerja mempunyai pengaruh positif terhadap kinerja pegawai kantor BPJS Kesehatan Cabang Palu.

\section{METODE PENELITIAN}

Jenis penelitian yang digunakan dalam peneilitian ini adalah penelitian replikasi. Menurut Muhammad Tazli di dalam kutipannya pada (http://medan.tribunnews.com/mobile/indexgintingreplikasidibenarkan-dalam-tugas-akhir). Penelitian replikasi adalah penelitian yang memodifikasi penelitian orang lain. Penelitian dapat juga mereplikasi penelitian orang lain tetapi memasukan ide dan gagasan baru dengan merubah cara pengolahan data, mengganti variabel, merubah cara pengukuran data.

Lokasi penelitian ini bertempat pada kantor BPJS Kesehatan Cabang Palu Jl.Sisingamangaraja No 31 Palu Sulawesi Tengah. Alasan penelitian dilakukan di BPJS Kesehatan Cabang Palu karna peneliti melihat adanya fenomena yang terkait dengan variabel penelitiaan serta peneliti ingin mengetahui seberapa besarkah pengaruh kompensasi dan disiplin kerja terhadap kinerja pegawai kantor BPJS Kesehatan Cabang Palu. Selanjutnya sampel adalah bagian dari jumlah dan karakteristik yang dimiliki oleh populasi tersebut (Sugiyono, 2014:81). Jumlah populasi dalam pebelitian ini hanya 36 orang, sehingga teknik pengambian sampel yang digunakan, yaitu menggunakan metode sampel jenuh. Istilah lain sampel jenuh adalah sensus, dimana semua anggota populasi dijadikan sampel (Sugiyono, 2014:85). Adapun metode pengumpulan data dalam penelitian ini:

1. Observasi

Observasi adalah teknik pengumpulan data dengan cara melakukan pengamatan langsung ke objek penelitian dan mempelajari segala sesuatu yang berkaitan dengan masalah yang akan diteliti disebuah organisasi agar mengetahui permasalahan sebenarnya.

2. Wawancara

Wawancara adalah teknik pengumpulan data dengan cara tanya jawab serta berhadapan langsung antara penanya dengan penjawab.

3. Kuesioner

Kuesioner adalah teknik pengumpulan data dengan cara membuat daftar pertanyaan yang berkaitan dengan penelitian dan kemudian disebarkan langsung kepada responden untuk mengisi kuesioner tersebut.

Metode analisis data yang digunakan adalah analisis regresi linear berganda adalah suatu alat analisis yang bisa digunakan untuk mengetahui pengaruh variabel X (kompensasi dan Disiplin Kerja) terhadap variabel Y (kinerja pegawai). Adapun model umum bentuk persamaan alat analisis statistik parametrik Regresi Linear Berganda (Multiple Linear Regression). Menurut Sanusi (2014:135), dapat digambarkan sebagai berikut:

$\mathrm{Y}=\mathrm{a}+\mathrm{b}_{1} \mathrm{X}_{1}+\mathrm{b}_{2} \mathrm{X}_{2}+\mathrm{e}$

Dimana:

$$
\begin{array}{ll}
\mathrm{Y} & =\text { Kinerja } \\
\mathrm{X}_{1} & =\text { Kompensasi } \\
\mathrm{X}_{2} & =\text { Disiplin Kerja } \\
\mathrm{a} & =\text { Konstanta } \\
\mathrm{b}_{1}, \mathrm{~b}_{2}, & =\text { Koefisien regresi } \\
\mathrm{e} & =\text { Faktor pengganggu di luar model }
\end{array}
$$


Armansyah, A.

\section{HASIL DAN PEMBAHASAN}

Tabel.1

Hasil Regresi Linear Berganda

\begin{tabular}{|c|c|c|c|c|c|c|}
\hline \multicolumn{2}{|c|}{ Model } & \multicolumn{2}{|c|}{ Unstandardized Coefficients } & $\begin{array}{l}\text { Standardized } \\
\text { Coefficients }\end{array}$ & \multirow[t]{2}{*}{$\mathrm{T}$} & \multirow[t]{2}{*}{ Sig. } \\
\hline & & B & Std. Error & Beta & & \\
\hline & (Constant) & 1.184 & .484 & & 2.447 & .020 \\
\hline 1 & KOMPENSASI (X1) & .363 & .125 & .391 & 2.908 & .006 \\
\hline & DISIPLIN KERJA (X2) & .345 & .101 & .459 & 3.416 & .002 \\
\hline \multicolumn{7}{|c|}{ Multiple $\mathrm{R}=0,725 \mathrm{~F}$ - hitung $=18.281$} \\
\hline \multicolumn{3}{|c|}{ R Square $\left(\mathrm{R}^{2}\right)$} & 0,000 & & & \\
\hline
\end{tabular}

Sumber: Output For Windows Release 21.0, 2017

Berdasarkan nilai dari tabel.1 diatas, maka persamaan regresi linear berganda dapat dirumuskan sebagai berikut:

$$
Y=1.184+0,363 X 1+0,345 X 2
$$

Berdasarkan persamaan tersebut maka dapat dinyatakan bahwa variabel independen (X1 dan X2) memberi pengaruh positif terhadap variabel dependen $(\mathrm{Y})$.

1. Nilai konstanta (a) adalah 1,184, artinya apabila variabel kompensasi (X1) dan disiplin kerja (X2) nilainya 0, maka kinerja pegawai Kantor BPJS Kesehatan Cabang Palu tetap positif 1,184.

2. Nilai koefisien regresi variabel kompensasi (X1) bernilai positif yaitu 0,363 . Hal ini menyatakan bahwa nilai kompensasi meningkat maka akan meningkatkan kinerja pegawai Kantor BPJS Kesehatan Cabang Palu.

3. Nilai koefisien regresi variabel disiplin kerja (X2) bernilai positif yaitu 0,474. Hal ini menyatakan bahwa nilai disiplin kerja meningkat maka akan meningkatkan kinerja pegawai Kantor BPJS Kesehatan Cabang Palu.

\section{Uji F}

Tabel 2

Hasil Uji Simultan (Uji F)

ANOVA $^{a}$

\begin{tabular}{|rr|r|r|r|r|r|}
\hline Model & & Sum of Squares & Df & Mean Square & F & Sig. \\
\hline & Regression & 1.865 & 2 & .932 & 18.281 & $.000^{\mathrm{b}}$ \\
1 & Residual & 1.683 & 33 & .051 & & \\
& Total & 3.548 & 35 & & & \\
\end{tabular}

Sumber: Output For Windows Release 21.0, 2017 
Berdasarkan hasil uji regresi pada tabel di atas, diperoleh Sig.Fsebesar 0,000 $<0,05$, yang dapat diartikan bahwa variabel kompensasi dan disiplin kerja secara simultan berpengaruh signifikan terhadap variabel kinerja pegawai. Berdasarkan hasil tersebut dapat disimpulkan bahwa H0 ditolak dan Ha diterima.

\section{Uji t}

Uji t dilakukan dengan membandingkan nilai t signifikansi lebih kecil dari $\square=0,05$ maka dapat dipastikan bahwa variabel independen berpengaruh signifikan terhadap variabel dependen, sebaliknya jika nilai t signifikansi lebih besar dari $\square=0,05$ maka dapat dipastikan bahwa variabel independen berpengaruh tidak signifikan terhadap variabel dependen, dapat dijelaskan hasil uji t dari variabel independen adalah sebagai berikut:

a. Kompensasi (X1)

Variabel kompensasi memiliki tingkat signifikansit sig. $(0,006)<\alpha(0,05)$. Hal ini menunjukkan bahwa hipotesis yang menyatakan"Kompensasi secara parsial berpengaruh signifikan terhadap kinerja pegawai Kantor BPJS Kesehatan Cabang Palu" terbukti atau bahwa H0 ditolak dan Ha diterima.

b. Disiplin Kerja (X2)

Variabel disiplin kerja memiliki tingkat signifikansi t sig. $(0.002)<\alpha(0,05)$. Hal ini menunjukkan bahwa hipotesis yang menyatakan "Disiplin Kerja secara parsial berpengaruh signifikan terhadap kinerja pegawai Kantor BPJS Kesehatan Cabang Palu” terbukti atau bahwa H0 ditolak dan Ha diterima.

\section{PEMBAHASAN}

\section{Kompensasi dan Disiplin Kerja Berpengaruh Terhadap Kinerja Pegawai}

Kompensasi dan disiplin kerja meruapakan faktor penting dalam menunjang kinerja pegawai, karena dengan adanya kompensasi dan disiplin kerja seorang pegawai maka dapat meningkatkan mutu kerja sebuah organisasi. Berdasarkan penelitian yang dilakukan di BPJS Kesehatan Cabang Palu menunjukan bahwa, BPJS Kesehatan Cabang Palu telah memberikan kompensasi dengan baik. Kompensasi tersebut dalam bentuk; 1) gaji yaitu kompensasi yang diterima pegawai setiap bulan; 2) insentif yaitu kompensasi yang diberikan untuk menunjang kinerja pegawai; 3) bonus yaitu kompensasi yang diberikan apabila kinerja pegawai melebihi standar; 4) tunjangan yaitu dimana kompensasi ini pegawai berhak untuk mendapatkannya. Selain itu BPJS Kesehatan Cabang Palu juga menerapkan disiplin kerja dengan baik, disiplin kerja tersebut ialah; 1) disiplin waktu yaitu pegawai harus menaati aturan jam masuk kerja, istirahat kerja dan pulang kerja yang telah ditetapkan; 2) disiplin administratif yaitu pegawai harus menaati aturan dalam memakai seragam yang telah ditetapkan; 3) disiplin moral yaitu pegawai harus menaati aturan mengerjakan tugas dalam kurun waktu yang telah ditetapkan.

Berdasarkan hasil uji regresi, diperoleh Sig.F sebesar 0,000 < 0,05,yang dapat diartikan bahwa variabel kompensasi dan disiplin kerja secara simultan berpengaruh signifikan terhadap variabel kinerja pegawai. artinya bahwa kompensasi dan disiplin kerja berperan dalam upaya untuk mendukung peningkatan kinerja karyawan pada kantor BPJS Kesehatan Cabang Palu, yang artinya kalau mau meningkatkan kinerja karyawan, BPJS Kesehatan Cabang Palu harus memperhatikan kompensasi dan disiplin kerja karyawan.

Hasil penelitian ini sejalan dengan penelitian yang dilakukan Naibaho dkk (2016) dan Mahardika dkk (2016) menunjukan bahwa, hasil penelitian ini dimana disiplin kerja dan kompensasi secara simultan berpengaruh signifikan terhadap Kinerja Karyawan pada RSUP Prof. Dr. R.D. Kandou, Manado. Masing-masing Disiplin Kerja dan Kompensasi secara parsial juga berpengaruh signifikan terhadap Kinerja Karyawan. 


\section{Kompensasi Berpengaruh Terhadap Kinerja Pegawai}

Kompensasi juga merupakan hal penting, yang merupakan dorongan atau motivasi utama seorang karyawan untuk bekerja disuatu perusahaan. dengan adanya kompensasi yang diberikan maka kelangsungan hidup perusahaan dapat dipertahankan dan tujuan perusahaan dapat tercapai secara efektif dan efisien.

Berdasarkan penelitian yang dilakukan di BPJS Kesehatan Cabang Palu menunjukan bahwa, BPJS Kesehatan Cabang Palu memberikan berbagai macam kompensasi untuk menunjang kinerja pegawainya. misalnya kompensasi langsung seperti pemberian gaji yang diterima pegawai setiap bulan, selain itu BPJS Kesehatan Cabang Palu juga memberikan insentif apabila kinerja pegawainya melebihi standar kerja yang telah ditentukan, dengan tujuan memotivasi pegawai agar memiliki produktifitas yang tinggi dan untuk menunjang kinerja pegawainya. bonus juga merupakan kompensasi yang diberikan BPJS Kesehatan Cabang Palu kepada pegawainya dengan menggunakan system target dan prestasi kerja dengan adanya raport yang dibuat setiap triwulan sekali, raport ini dibuat untuk menentukan bonus dan perhitungan tercapainya target kinerja setiap pegawai yang telah ditentukan oleh BPJS kesehatan cabang palu. Selain itu BPJS Kesehatn Cabang Palu juga memberikan kompensasi tidak langsung misalnya tunjangan untuk kesehatan kepada pegawainya dan tunjangan untuk pegawai pada saat tidak bekerja seperti cuti tahun pegawai, cuti hari besar dan cuti karena alasan penting.

Berdasarkan hasil uji parsial, penelitian ini menunjukkan bahwa kompensasi secara parsial berpengaruh signifikan terhadap kinerja pegawai BPJS Kesehatan Cabang Palu. Artinya hipotesis kedua penelitian ini diterima. Selanjutnya, berdasarkan hasil uji regresi linear berganda menunjukkan bahwa kompensasi berpengaruh positif terhadap kinerja. Artinya, apabila BPJS Kesehatan Cabang Palu memberikan kompensasi dengan lebih baik lagi, maka akan lebih baik pula kineja pegawai BPJS Kesehatan Cabang Palu.Hal ini sejalan dengan yang dikemukakan Hasibuan (2016) yang menyatakan bahwa pemberian kompensasi yang semakin baik akan mendorong karyawan untuk bekerja dengan semakin baik dan produktif.

\section{Disiplin Kerja Berpengaruh Terhadap Kinerja Pegawai}

Disiplin kerja merupakan faktor penting yang harus dimiliki oleh seorang pegawai karena dengan adanya disiplin kerja dari seorang pegawai maka akan mempermudah sebuah organisasi dalam mencapai tujuannya. Berdasarkan penelitian yang dilakukan di BPJS Kesehatan Cabang Palu menunjukan bahwa, BPJS Kesehatan Cabang Palu menerapkan disiplin kerja untuk menunjang kinerja pegawainya dengan baik. Misalnya disiplin waktu dimana pegawai masuk kerja, istirahat kerja dan pulang kerja semuanya diatur oleh pihak BPJS Kesehatan Cabang Palu. artinya apabila pegawai melanggar peraturan tersebut maka pegawai akan dikenakan sanksi. BPJS Kesehatan Cabang Palu juga menerapkan disiplin administratif yaitu mengerjakan aturan atau kaedah yang telah ditetapkan pihak BPJS Kesehatan Cabang Palu misalnya memakai seragam yang sesuai dengan apa yang telah ditetapkan. artinya apabila pegawai melanggar peraturan tersebut maka pegawai akan dikenakan sanksi.

Selain itu BPJS Kesehatan Cabang Palu juga menerapkan disiplin moral yaitu pegawai harus mengerjakan tugas yang telah diberikan dan disetiap pegawai berperilaku sopan terhadap pegawai lainnya agar tercipta hubungan yang baik dalam kerjasama tim. artinya apabila pegawai melanggar peraturan tersebut maka pegawai akan dikenakan sanksi. Hal ini menyatakan bahwa disiplin kerja merupakan faktor penting dalam peningkatan kinerja pegawai Kantor BPJS Kesehatan Cabang Palu. Karena dengan adanya peratutan disiplin kerja yang ketat dan pemberian sanksi tegas, maka para pegawai lebih taat terhadap semuah peraturan yang telah ditetapkan. dengan adanya sikap taat untuk mematuhi peraturan yang berlaku maka para pegawai mampu menciptakan kinerja yang berkualitas. 
Berdasarkan hasil uji parsial, penelitian ini menunjukkan bahwa disiplin kerja secara parsial berpengaruh signifikan terhadap kinerja pegawai BPJS Kesehatan Cabang Palu. Artinya hipotesis ketiga penelitian ini diterima. Selanjutnya, berdasarkan hasil uji regresi linear berganda menunjukkan bahwa disipllin kerja berpengaruh positif terhadap kinerja. Artinya, apabila BPJS Kesehatan Cabang Palu menerapkan disiplin kerja dengan lebih baik lagi, maka akan lebih baik pula kineja pegawai BPJS Kesehatan Cabang Palu. Hal ini sejalan dengan pendapat yang dikemukan oleh Payaman (2016) menyatakan bahwa disiplin kerja yaitu merupakan fungsi operatif dari manajemen sumber daya manusia yang terpenting, karena semakin baik disiplin karyawan semakin tinggi prestasi kerja yang dapat dicapainya.

\section{KESIMPULAN DAN SARAN}

\section{Kesimpulan}

Berdasarkan dari hasil analisis dan pembahasan yang dilakukan ,maka dapatdisimpulkan sebagai berikut:

1. Kompensasi dan Disiplin kerja secara simultan berpengaruh positif dan signifikan terhadap kinerja pegawai Kantor BPJS Kesehatan Cabang Palu.

2. Kompensasi berpengaruh positif dan signifikan terhadap kinerja pegawai di Kantor BPJS Kesehatan Cabang Palu.

3. Disiplin kerja berpengaruh positif dan signifikan terhadap kinerja pegawai di Kantor BPJS Kesehatan Cabang Palu.

\section{Saran}

Berdasarkan dari hasil analisa dan kesimpulan yang dilakukan, maka beberapa saran yang dapat diberikan adalah sebagai berikut:

1. Diharapkan kepada BPJS Kesehatan Cabang Palu agar lebih memperhatikan pemberian kompensasi terutama pada indikator insentif, dimana BPJS Kesehatan Cabang Palu harus memberikan insentif apabila kinerja pegawainya meningkat. Oleh karena itu disarankan kepada BPJS Kesehatan Cabang Palu membuat program mengenai reward pada karyawan seperti mengadakan program "Karyawan terbaik" yang dilaksanakan setiap bulan Program ini akan membantu perusahaan untuk dapat melihat karyawan mana saja yang memiliki kinerja terbaik dan dapat diberikan reward berupa kenaikan jabatan.

2. Diharapkan kepada BPJS Kesehatan Cabang Palu agar lebih meningkatkan disiplin kerja pegawainya terutama pada indikator disiplin moral. Oleh karena itu disarankan kepada BPJS Kesehatan Cabang Palu agar memberikan sanksi tegas terhadap karyawan yang tidak disiplin terutama yang berkaitan dengan pegawai yang tidak mengerjakan tugas yang diberikan.

3. Diharapkan kepada BPJS Kesehatan Cabang Palu agar lebih meningkatkan pemberian kompensasi terutama pada indikator insentif dan memberikan sanksi tegas kepada pegawai yang melanggar peraturan disiplin kerja, sehingga dengan memperhatikan faktor-faktor tersebut maka akan meningkatkan produktifitas kerja dari seorang pegawai, sehingga akan mempermudah BPJS Kesehatan Cabang Palu dalam mencapai tujuannya.

\section{REFERENSI}

Hasibuan Malayu S.P. (2009) Manajemen : Dasar Pengertian dan Masalah, Edisi Revisi. Jakarta: Bumi Aksara.

Hasibuan Malayu S.P. (2016) Manajemen : Manajemen Sumber Daya Manusia, Edisi Revisi. Jakarta: Bumi Aksara.

Fahmi, Irham (2010), Manajemen Kinerja. Bandung: Alfabeta. 
Armansyah, A.

Mahardika, Bagia, Yulinthini, (2016) Pengaruh Kompensasi Dan Disiplin Keerja Terhadap Kinerja Karyawan Pada Hotel Puri Bugis Lovina. Jurnal Bisma Universitas Pendidikan Ganesha Jurusan Manajemen, Vol. 4, Tahun (2016).

Mangkunegara. A. A. Anwar Prabu, 2012. Perilaku Konsumen. Cetakan I. PT. Eresco Bandung, 1998.

Mangkunegara. A. A. Anwar Prabu, 2013. Manajemen Sumber Daya Manusia Perusahaan. Bandung: PT Remaja Rosdakarya

Mangkunegara. A. A. Anwar Prabu, (2015). Manajemen Sumber Daya Manusia Perusahaan. Bandung: PT Remaja Rosdakarya.

Naibaho, Kawet, Dan Kojo (2016). Pengaruh Disiplin Dan Kompensasi Terhadap Kinerja Karyawan Rsup Prof Dr. Rd. Kandou Manado. Jurnal Berkala Ilmiah Efisiensi, Volume 16, No. 02, Tahun 2016.

Rachmawati, Ike Kudsyah. (2008). Manajemen Sumber Daya Manusia. Yogyakarta: Andi.

Rivai, (2003) Manajemen Sumber Daya Manusia untuk Perusahaan. Jakatra: PT Raja Grafindo Persada.

Rivai, (2008). Manajemen Sumber Daya Manusia untuk Perusahaan. Jakatra: PT Raja Grafindo Persada

Rivai, (2009). Manajemen Sumber Daya Manusia untuk Perusahaan. Jakatra: PT Raja Grafindo Persada

Sanusi, 2014. Metodologi Penelitian Bisnis. Jakarta: Salemba Empat.

Soetrisno PH. (1992). Kapita Selekta Ekonomi Indonesia, Edisi Kedua, Yogyakarta: Penerbit Andi Offset.

Sutrisno, Edy.(2009). Mnajemen Sumber Daya Manusia, Jakarta: Kencana.

Sugiyono, (2014). Metode Penelitian Kuantitatif, Kualitatif, Dan R\&D. Bandung: Alfabeta.

Umar. (2007). Metode Penelitian Untuk Sripsi Dan Tesis Bisnis. Jakarta: PT. Raja Grafindo Persada. 